\title{
An Analysis of Selected Accounting Provisions of the Tax Reform ACt of 1986
}

\author{
James F. Hopson \\ College of Business Administration \\ Texas A \& I University \\ Kingsville, Texas \\ Jack R. Ethridge \\ College of Business Administration \\ Stephen F. Austin University \\ Nacogdoches, Texas
}

The enactment of the Tax Reform Act of 1986 (TRA-86) [7] has created numerous changes in the tax system which have impacted financial reporting. This article analyzes selected TRA-86 provisions and highlights their effects on financial reporting and the deferred tax accounts in particular, since the effects of these changes are generally to accelerate taxable income and defer deductions. The overall significance and impact of these changes will vary among business enterprises. However, it is likely that many of these changes will affect tax and financial reporting as well as tax planning.

One important consequence of the TRA-86 is that it changed the acceptable tax method for accounting for certain types of transactions. The changes in accounting methods will affect tax reporting, and as a consequence, deferred taxes reported on the balance sheet may be affected because of the timing differences created due to the differences between taxable and financial incomes.

\section{Cash Method}

TRA-86 will place restrictions on the use of the cash method by prohibiting $C$ corporations, partnerships with any $C$ corporation partners, tax shelters, and tax-exempt trusts with unrelated business income from using the cash method or some modification of reporting partly on a cash basis. However, TRA-86 will allow certain exceptions to the new rule. Businesses with average annual gross receipts of $\$ 5$ million or less for the three preceding tax years, qualified personal service corporations, and farming and timber businesses may continue to use the cash method. A qualified personal service corporation is defined as a corporation in which 95 percent of the stock is owned by employees or retired employees and where all the activities of the corporation are in the field of

Journal of Business Strategies, Volume 5, Number 1 (Spring 1988) 
health, law, engineering, architecture, accounting, actuarial science, performing arts, or consulting.

The restriction on the use of the cash method of accounting will place tax reporting on similar footing with financial reporting. Under most financial reporting circumstances, the use of the cash method is restricted to situations where the probability of recovering product or service costs is remote. Therefore, the move towards accrual accounting for tax reporting may reduce the number of timing differences created each year by certain reporting companies. With the complexities involved in determining deferred taxes, any relief in this area should be welcome because of the savings in time and cost.

The change in accounting method is required for tax years beginning after December 31,1986 . The change is treated as if initiated by the taxpayer, but it will be automatically approved by the Internal Revenue Service (IRS) without the taxpayer receiving special permission. Therefore, any adjustment required by Internal Revenue Code (IRC) [8] Section 481 as a result of the changes shall be recognized over a period not to exceed four years. Hospitals required to change their accounting method may recognize the change over a period not to exceed ten years. Corporations affected by the required change may elect to be taxed as an S Corporation, which may lower the total tax bite since top marginal tax rates for individuals will be lower than that of corporations under TRA-86.

\section{Dollar-Value LIFO}

The TRA-86 will make it possible for businesses with average gross receipts of $\$ 5$ million or less to elect, without obtaining IRS' permission, a simplified dollar-value LIFO. Last-in, First-out (LIFO) is an inventory method which allows taxpayers to match current cost with current revenue, with the objective of mitigating the effects of inflation. For many small businesses, the use of LIFO may be complex and very time consuming. To overcome some of these problems, a simplified approach called Dollar-Value LIFO was developed. This method is based upon: (1) using price indexes related to inventory, instead of units and unit costs; and (2) applying the price indexes to groups of products called inventory layers, rather than to each individual product. These features have reduced the complexity of LIFO and made it available to small businesses. Specifically, the new LIFO method will require the development of inventory pools grouped by Bureau of Labor Statistics (BLS) Producer and Consumer general price index categories. For retailers, the pools are based on eleven general categories from the "Consumer Price Index for all Urban Consumers," and for other taxpayers the pools are based on 15 general categories from the "Producer Prices and Price Indexes for Commodity Groupings and Individual Items." The indexing of annual cost changes will be developed by using BLS indexes and cumulative indexes developed by the link-chain-method. 
The use of LIFO is one of the few areas where tax and financial accounting must agree. Therefore, as the IRS changes its rules for LIFO, financial accounting must also change. This is usually considered one of the disadvantages of using LIFO for financial reporting. However, the use of LIFO for financial reporting does not mean that a different method cannot be used for internal reporting.

\section{Long-Term Contracts}

Generally, long-term contracts are defined as contracts for a building, installation, construction or manufacture that is not completed within the taxable year in which it was started. There are two primary methods for accounting for long-term contracts: (1) the completed-contract method, and (2) the percentage-of-completion method. The basic difference between the two methods concerns the timing of profit recognition during the contract. The completed-contract method recognizes the entire profit on the contract in the year in which the contract was finished, whereas the percentage-of-completion method recognizes a proportionate share of the profit during each year of the contract. TRA-86 will limit the use of the completed-contract method for contracts entered into after February 28, 1986, to taxpayers who are engaged in the construction or improvement of real property where construction is expected to be completed within two years of the contract date, and have average annual gross receipts of $\$ 10$ million of less for the three preceding tax years. Under TRA-86, as modified by the Revenue Act of 1987, there will be two acceptable methods available for companies who cannot use the completedcontract method: (1) percentage-of-completion of (2) the new percentage-ofcompletion-capitalized cost method. In terms of application, the percentageof-completion method may be used as before with an exception for changes in the capitalization rules. The second approach is a hybrid approach which calls for 40 percent of the contract to be reported by using the percentage-ofcompletion method and for 60 percent to be accounted for using the company's normal method of accounting for long-term contracts. The Revenue Act of 1987 modified the second approach for contracts entered into after October 13, 1987. The 1987 Act now requires that 70 percent of the contract to be accounted for using the percentage-of-completion method and 30 percent of the contract using the completed contract method.

Under Generally Accepted Accounting Principles (GAAP), long-term construction contracts should be reported by using either the completed-contract method or the percentage-of-completion method. However, the two methods should not be viewed as acceptable alternatives for the same circumstances. According to Statement of Position 81-1, there is a preference for use of the percentage-of-completion method when certain conditions are met ([4], para. 23). The limitation on the use of the completed-contract method for tax purposes will bring it more in line with financial accounting. However, the criteria for selecting the completed-contract method are still different between tax 
and financial accounting. Also, the percentage-of-completion-capitalized cost method is not acceptable for financial reporting. Therefore, under certain situations it is likely that an enterprise will be required to select different methods for tax and financial reporting. This will result in the need to create a deferred tax account to record the effect of the timing differences. Taxpayers subject to the alternative minimum $\operatorname{tax}(\mathrm{AMT})$ may elect to use the percentage-of-completion method to reduce the effects of AMT while also avoiding the differences in tax and financial accounting.

\section{Bad Debts}

For tax years beginning after 1986, TRA-86 eliminates the use of the bad debt reserve method of deducting uncollectible accounts for enterprises other than certain financial institutions. Congress believed the reserve method allowed enterprises to deduct losses for uncollectible accounts for tax purposes that may or may not occur in the future. Congress generally believed this approach was inconsistent with the treatment of other deductions. Existing reserves at the beginning of the 1987 tax year will be taken into income ratably over four years as an IRC Section 481 adjustment, while any debt becoming worthless is deducted in the year it becomes worthless.

This view is completely contrary to accounting theory which supports the need to recognize uncollectible accounts in the year of sale so that current revenues may be matched with related expenses. This change in tax policy will again result in the need to create a deferred tax account to record the effect of the timing differences. It is anticipated that this change will affect most enterprises because of the limited acceptability of the direct write-off method for financial reporting. The originating timing difference will most likely result in an increase in the deferred charge account because the allowance method will allow the deduction of bad debts losses before they are actually determined to occur (making taxable income less than financial income).

For 1986, those fiscal year corporations whose year end tax return has not yet been filed may want to consider increasing adjustments to bad debt expense to the maximum reasonable amount. This procedure allows a greater deduction for this higher tax year, allowing the taxpayer to recognize the reserve as income over the next four years (when tax rates are lower), but deduct receivables when they are actually written off (usually within the next year).

\section{Capitalization of Inventory Cost}

TRA-86 changes the types of costs that must be included in inventory costs for tax years beginning after 1986 . Under the old law all direct material and labor costs plus certain indirect manufacturing costs were required to be included in inventory and deducted as part of cost of goods sold. TRA-86 expands the types of indirect costs that must now be capitalized in inventory and deducted 
as part of cost of goods sold. In effect, those costs which were once considered period costs (i.e., costs that are deducted as an expense when incurred and not included in the cost of the product) will now be considered product costs (i.e., costs included as part of the cost of the product and not deducted as an expense until the product is sold). This change will result in an increase in the valuation of inventory through the deferral of deductions which will increase a company's taxable income.

The indirect costs which must now be capitalized include:

1. costs related to purchasing inventory;

2. costs related to repackaging and assembly, incurred while in the enterprise's possession;

3. storage costs;

4. part of general and administrative costs related to the above functions;

5. part of pension and profit-sharing costs; and

6. certain interest costs (including imputed interest).

These rules will only affect inventory valued at cost; and therefore, will not affect inventory valued at market using the lower of cost or market method. However, the rules do apply to inventory on hand at the beginning of the 1987 tax year. This inventory must be revalued using the new rules and any inventory value adjustment must be recognized over a four year period under IRC Section 481.

The impact of the rule changes for valuation of inventory for financial accounting will probably vary from enterprise to enterprise. Under GAAP, the costs to be included in inventory normally include all direct and indirect costs necessary to acquire and prepare the inventory for sale. However, in practice, the treatment of certain costs, such as the costs of the purchasing department and the cost of pensions, may be recorded as period or product costs. Under TRA-86, one situation where differences between tax and financial valuation of inventory will probably arise involves the capitalization of interest to be included in the cost of inventory. The overall implication of these rule changes will involve the need to create deferred tax account(s) to record the effect of the timing differences due to the different classification of period and product costs. The increased tax cost of carrying inventory can be minimized by increasing inventory turnover and lowering ending inventory. The just-in-time inventory technique lowers inventory, provides cash management benefits, and produces tax benefits as well. 


\section{Installment Sales}

For sales made after February 28, 1986, in taxable years ending after December 31,1986 , the installment method of accounting for income tax purposes is not allowed in three situations:

1. certain installment receivables based on the enterprise's outstanding debt;

2. revolving credit plans; and

3. sales of publicly traded property.

Additionally, the Revenue Act of 1987 generally repealed the installment method for sales of property by dealer occurring after December 31,1987 .

The limitation on the use of the installment method is in line with the conclusion reached by the Accounting Principles Board in 1966. The Board stated, "... except for special circumstances, the installment method of recognizing revenue is not acceptable for reporting purposes" ([3], para. 12). Even with the limitation on the use of the installment method, the problem of recording the effect of timing differences may still exist because of the possibility of using different accounting methods to determine financial and taxable income.

Short-term sales are taxed at the ordinary income tax rate and are not eligible for the special $28 \%$ capital gain tax rate in 1987 . Therefore, taxpayers who previously sold short-term securities at year end but deferred recognizing the gain on the settlement date until the next year should consider deferring not only year-end short-term sales, but also any short-term sales with built-in gains until next year when tax rates are lower. Taxpayers desiring to lock in gains may either sell short against the tax or purchase a put option that may be exercised early next year.

Taxpayers affected by the AMT may elect out of installment sale treatment and narrow the differences between AMT and the regular tax. Taxpayers should evaluate the effects of this on future years since AMT planning is a long-range process after TRA-86.

\section{Potential Accounting Issues}

As stated previously, TRA-86 will create changes that will impact different enterprises in different ways. Each firm will be faced with questions concerning how to recognize and report the effects of changes required by TRA-86 in their financial statements. Some of the questions to be raised involve how to account for certain provisions during the transition phase, rate reductions, the alternative minimum tax, and modification of the investment tax credit carryover. These and other questions have already been addressed by the Financial Accounting Standard Board (FASB). In response to many questions, FASB proposed a Technical Bulletin [5], and in December 1987, FASB adopted Exposure Draft (ED) [6] with minor changes as FASB 96, "Accounting for Income Tax." 
The Technical Bulletin addressed two major issues: (1) in what period(s) should the tax effects of any retroactive provision of TRA-86 be recognized and (2) what changes should be made to deferred tax accounts because of the rate reductions. In addressing question one, FASB indicated that potential tax effects of retroactive provisions on interim and annual periods to the October 23,1986 , enactment date should be recognized as a part of income tax expense in the financial statements of the interim and annual period that included the enactment date. The Technical Bulletin takes the position "... that the event to be recognized is the enactment of the new legislation , and therefore, the appropriate period of enactment" ([5], para. 10). The second question concerned whether it would be appropriate to adjust deferred tax accounts created prior to the enactment date of TRA-86 for changes in income tax laws and rates. FASB responded by indicating the provisions of $A P B$ Opinion No. 11 [1] are still in effect and therefore the deferred tax accounts should not be adjusted except where required by existing provisions. The guidelines provided by $A P B$ Opinion No. 11 indicate that the deferred approach should be used to account for the tax effect of a timing difference between taxable and financial income. Under this approach, the tax effect of a timing difference should be determined in the year in which the timing difference originated and not adjusted until the difference reverses. Accordingly, once a deferred tax account has been established for a timing difference no adjustment is made to the deferred tax account until it reverses. This would be true even if the current tax rate is different from the original rate used to establish the account or will be different when the timing difference reverses.

The ED [6] would allow reductions in the future income tax rate to be reflected in the deferred tax accounts immediately. FASB No. 96, adopted in December 1987, does not apply until years beginning after December 15, 1988. Companies may adopt the statement now, but it must be applied cumulatively as of the beginning of the year and it may be adopted retroactively by restating prior periods. FASB 96 would require a fundamental change in the method of accounting for deferred taxes from the deferred approach to the liability approach. The primary difference between the two approaches is that the liability approach would require deferred taxes to be adjusted for tax rate changes, which is not required under the deferred approach. This change will affect nearly all companies. The first application of this approach may create confusion and record-keeping problems. However, after the initial confusion and record-keeping problems are solved, it is generally believed that this approach should make accounting and reporting of deferred taxes more understandable because it focuses on a company's current or future tax return.

In addition, the Securities and Exchange Commission (SEC) has issued a release [9] which requires disclosure of material effects upon future liquidity including reversal of book/tax differences that have or have not been booked pursuant to $A P B$ Opinion No. 23, [2]. Companies desiring to quantify the 
effects may disclose upper and lower limits of the anticipated effects based upon the FASB exposure draft.

\section{Conclusion}

TRA-86 has introduced numerous changes in the tax law, many of which will have a direct impact on the financial condition of the business enterprise and subsequently upon the enterprise's financial reporting practices. Unfortunately, the effects of many of these changes are still being evaluated and will not be resolved in the near future.

A major issue that most business enterprises must face immediately is the problem of deferred taxes. As discussed in this article, TRA-86 will have a major impact on companies' deferred taxes through changes in the acceptable accounting methods. However, both the FASB and the APB have issued pronouncements designed to offer assistance to companies as they strive to account for and disclose the effects of the changes related to deferred taxes.

\section{References}

1. Accounting Principles Board. "Accounting for Income Taxes," Opinion No. 11. New York, NY: American Institute of Certified Public Accountants (1967).

2. Accounting Principles Board. "Accounting for Income Tax Special Areas," Opinion No. 23. New York, NY: American Institute of Certified Public Accountants (1972).

3. Accounting Principles Board. "Omnibus Opinion-1966," Opinion No. 10. New York, NY: American Institute of Certified Public Accountants (1967).

4. Construction Contractor Guide Committee of the Accounting Standards Division, AICPA. "Accounting for Performance of Construction-Type and Certain Production-Type Contracts," Statement of Position 81-1. New York, NY: American Institute of Certified Public Accountants (1981).

5. Financial Accounting Standards Board. "Accounting for Certain Effects of the Tax Reform Act of 1986," Proposed Technical Bulletin No. 86-a (1986).

6. Financial Accounting Standards Board. "Accounting for Income Taxes," Exposure Draft (1986).

7. Tax Reform Act of 1986. Statutes at Large, Vol. 1 (1986).

8. Internal Revenue Code of $1954, \S 481$. 
9. U. S. House of Representatives. Report of the Committee on Ways and Means, Tax Reform Act of 1986. H. R. 3838, 99th Congress, 1st Session (1985).

10. U. S. Congress. Conference Committee Report, Tax Reform Act of 1986. H. R. 3838, 99th Congress, 2nd Session (1986).

11. U. S. Senate. Report of the Committee on Finance, Tax Reform Act of 1986. H. R. 3838, 99th Congress, 2nd Session (1986). 